\title{
Pengaruh Metode Permainan Kata Teka-Teki Silang dan Anagram terhadap Penguasaan Kosakata Siswa Kelas IV
}

\author{
Siska Nurma Yunitasari ${ }^{1}$, Anang Santoso ${ }^{2}$, Ari Sapto ${ }^{3}$ \\ ${ }^{1}$ Pendidikan Dasar-Universitas Negeri Malang \\ ${ }^{2}$ Pendidikan Bahasa Indonesia-Universitas Negeri Malang \\ ${ }^{3}$ Pendidikan Sejarah-Universitas Negeri Malang
}

\begin{tabular}{l}
\hline \hline INFO ARTIKEL \\
\hline Riwayat Artikel: \\
Diterima: $27-01-2019$ \\
Disetujui: $16-02-2019$ \\
\hline
\end{tabular}

\section{Kata kunci:}

crossword puzzle; anagram; vocabulary mastery; teka-teki silang; anagram;

penguasaan kosakata

\author{
Alamat Korespondensi: \\ Siska Nurma Yunitasari \\ Pendidikan Dasar \\ Universitas Negeri Malang \\ Jalan Semarang 5 Malang \\ E-mail: siskanurma@gmail.com
}

\begin{abstract}
ABSTRAK
Abstract: Vocabulary mastery is crucial to be taught to elementary school students because it significantly affects the student's language skills. This research was aimed to explain the influence of wordplay method such as crosswords and anagramss toward the vocabulary mastery of elementary school students. This study used a pretest posttest control group design with a sample of 36 students. The hypothesis test carried out using anacova test. The result show that there is a significant effect on the wordplay method include crosswords and anagrams to vovabulary mastery with the sig. value of $0,000<$ 0,05 .
\end{abstract}

\begin{abstract}
Abstrak: Penguasaan kosakata sangat penting untuk diajarkan kepada peserta didik di sekolah dasar karena hal tersebut sangat memengaruhi keterampilan berbahasa peserta didik. Tujuan penelitian ini adalah untuk menjelaskan pengaruh metode permainan kata teka-teki silang dan Anagram terhadap penguasaan kosakata siswa sekolah dasar. Penelitian ini menggunakan pretest-posttest control group design dengan sampel 36 peserta didik. Uji hipotesis dilakukan dengan uji Anacova. Hasil penelitian menunjukkan bahwa terdapat pengaruh signifikan metode permainan kata teka-teki silang dan Anagram terhadap penguasaan kosakata dengan nilai Sig. $0,000<0,05$.
\end{abstract}

Secara umum, kemampuan berbahasa yang baik perlu dimiliki oleh seluruh warga negara khususnya warga negara Indonesia. Selain sebagai media komunikasi, bahasa juga digunakan sebagai media untuk mencapai kesejahteraan sosial (Zulela, 2013). Keterampilan berbahasa yang baik salah satunya dipengaruhi oleh keberagaman kosakata yang dimiliki seseorang. Tidak hanya jumlah kosakata yang dikuasai, tetapi juga jenis kosakata dan penggunaannya sesuai dengan konteks yang dibutuhkan. (Alqahtani, 2015) dalam penelitiannya menyimpulkan bahwa ketika seseorang mempunyai gagasan maka akan membutuhkan kosakata yang dapat digunakan untuk membantu dalam menyampaikan gagasan tersebut, dengan memilih kosakata yang sesuai dengan gagasan yang akan disampaikan. Kosakata tidak hanya penting bagi orang dewasa, melainkan sangat penting bagi setiap individu sedini mungkin ketika mereka sudah dapat melakukan proses komunikasi.

Menurut Hurlock (2009) kosakata yang harus dikuasai anak-anak usia SD ada dua jenis, yaitu kata-kata yang sering digunakan untuk berkomunikasi atau disebut juga kosakata umum, seperti kata kerja, kata benda, kata sifat, kata keterangan, kata ganti orang. Jenis kosakata lain yang harus dikuasai anak usia SD adalah kosakata khusus yang harus dikuasai anak-anak usia sekolah dasar seperti kosakata waktu, warna, uang, kosakata rahasia, kosakata populer, dan kosakata makian. Melalui kurikulum yang ada saat ini kedua jenis kosakata tersebut dapat diajarkan di bangku Sekolah Dasar dengan cara yang menyenangkan dan mengesankan. Berdasarkan hasil observasi di kelas IV SDIT Al-Istiqomah Pace didapat dua hasil, yaitu Pertama, peserta didik belum menguasai jenis kosakata khusus hal itu dapat dilihat dari peserta didik mengalami kesulitan dalam menyampaikan ide atau gagasan yang akan mereka tuangkan pada kegiatan menulis cerita. Kedua, dalam pembelajaran guru sudah menggunakan metode pembelajaran, tetapi guru kurang memperhatikan kesesuaian metode yang diterapkan dengan kebutuhan kelas. Guru menggunakan metode konvensional untuk menyampaikan semua jenis materi pembelajaran kepada peserta didik.

Berdasarkan pemaparan di atas terlihat adanya kesenjangan teori dengan temuan peneliti di lapangan sehingga untuk mengatasi permasalahan tersebut peneliti akan menggunakan metode permainan kata teka-teki silang dan Anagram untuk membantu peserta didik dalam memperkaya jenis kosakata mereka. Pemilihan metode permainan kata teka-teki silang dan Anagram dilandasi oleh pendapat Broadhead, dkk (2017) yang menyatakan bahwa ketika peserta didik diberikan lingkungan untuk bermain, hal tersebut dapat membantu guru dalam menyampaikan materi sehingga mendukung peserta didik untuk dapat 
belajar pada banyak ranah. (Semmar \& Al-thani, 2015) dalam penelitian yang dilakukan menyimpulkan bahwa anak-anak tidak memperoleh pengetahuan langsung dari luar, sebaliknya mereka harus membangun pengetahuan sendiri melalui interaksi dengan lingkungan dan interaksi dengan sosial. (Zirawaga, Olusanya, \& Maduku, 2017) mengemukakan bahwa teka-teki silang merupakan permainan yang berkaitan dengan teka-teki kata yang harus dilengkapi berdasarkan petunjuk atau soal yang telah disediakan. Anagram menurut (Muncer \& Knight, 2011) adalah mengubah susunan huruf menjadi sebuah kata dan memiliki makna yang berbeda. Anagram dapat digunakan dalam pembelajaran sebagai latihan untuk menambah penguasaan kosakata.

(Masri \& Najar, 2014; Perveen et al., 2016; Putra et al., 2014; Rohani \& Pourgharib, 2013) dan Wahyu (2017) di dalam penelitian yang mereka lakukan dapat disimpulkan bahwa pemberian metode permainan terlebih dengan jenis teka-teki silang dapat membantu peserta didik untuk mempelajari kosakata tentunya dengan suasana yang menyenangkan sesuai dengan kondisi alami anak-anak usia Sekolah Dasar. (Rosadi, 2017) dalam penelitiannya menyimpulkan bahwa penerapan Anagram dalam pembelajaran dapat meningkatkan penguasaan kosakata peserta didik. Oleh karena itu, bagi guru yang akan mengajarkan kosakata bahasa Indonesia kepada peserta didik Sekolah Dasar disarankan untuk menggunakan metode permainan kata tekateki silang dan Anagram. Tujuan penulisan artikel ini adalah untuk menjelaskan pengaruh metode permainan kata teka-teki silang dan Anagram terhadap penguasaan kosakata bahasa Indonesia siswa kelas IV di SDIT Al-Istiqomah Pace.

\section{METODE}

Penelitian ini merupakan kuantitatif dengan rancangan penelitian quasi experiment dan desain penelitian pretestposttest control group design. Kelompok penelitian terdiri dari kelompok eksperimen dan kontrol. Kedua kelompok akan diberikan pretest atau tes awal dan posttest atau tes akhir dengan soal yang sama. Proses belajar mengajar di kelompok eksperimen menggunakan metode permainan kata teka-teki silang dan Anagram, sedangkan di kelompok kontrol, pembelajaran menggunakan metode konvensional. Penelitian ini memiliki satu variabel bebas yaitu metode permainan kata teka-teki silang dan Anagram, serta satu variabel terikat yaitu penguasaan kosakata. Subjek penelitian adalah seluruh siswa kelas IV di SDIT Al-Istiqomah Pace yang berjumlah 18 anak pada kelompok eksperimen dan 18 anak pada kelompok kontrol. Penentuan subjek penelitian dilakukan dengan teknik cluster random sampling.

Perangkat yang dipakai untuk mengumpulkan data terdiri atas silabus, RPP, pedoman pengamatan pengelolaan pembelajaran, dokumentasi, dan tes tulis. Tes tulis yang diberikan kepada sampel penelitian berupa jawaban singkat sebanyak 12 butir soal dengan reliabilitas 0,716 , peserta didik akan diminta untuk menentukan antonim dan sinonim dari kata-kata yang terdapat pada lembar soal.

Teknik analisis data dilakukan dengan menggunakan bantuan SPSS 23 for window. Uji prasyarat yang harus dipenuhi sebelum pengujian hipotesis adalah uji normalitas data dan uji homogenitas. Uji hipotesis yang digunakan adalah uji Anacova untuk mencari tahu keberadaan pengaruh penerapan metode permainan kata teka-teki silang dan Anagram di kelompok eksperimen.

\section{HASIL}

Data penelitian di kelas IVA dan kelas IVB di SDIT Al-Istiqomah Pace yaitu berupa nilai pretest yang didapat sebelum diberikan perlakuan dan nilai posttest yang didapat setelah diberikan perlakuan pada masing-masing kelompok. Perolehan nilai pretest dan posttest di kelompok eksperimen dan kelompok kontrol disajikan pada tabel 1.

Tabel 1. Distribusi Nilai Pretest dan Posttest Penguasaan Kosakata

\begin{tabular}{lccccccc}
\hline \multirow{2}{*}{ Kelas } & \multicolumn{3}{c}{ Pretest } & \multicolumn{3}{c}{ Posttest } & siswa \\
\cline { 2 - 7 } & Nilai Terendah & Nilai Tertinggi & Rata-rata & Nilai Terendah & Nilai Tertinggi & Rata-rata & siswarn \\
\hline Eksperimen & 35 & 71 & 52 & 56 & 85 & 72 & 18 \\
Kontrol & 20 & 71 & 50 & 20 & 78 & 49 & 18 \\
\hline
\end{tabular}

Berdasarkan tabel 1 disimpulkan bahwa kemampuan awal pada kelompok eksperimen dan kontrol adalah sama. Hal tersebut dapat dilihat dari nilai pretest pada kedua kelompok. Kemudian setelah diberikan perlakuan metode permainan kata teka-teki silang dan Anagram di kelompok eksperimen dan metode konvensional di kelompok kontrol diketahui terdapat perbedaan signifikan dimana pada kelompok eksperimen nilai rata-rata penguasaan kosakata lebih tinggi dibanding kelas kontrol.

Persyaratan yang harus dipenuhi sebelum uji hipotesis dilakukan yaitu uji normalitas data dan homogenitas. Berdasarkan data hasi penelitian didapat uji normalitas pada kelompok eksperimen dan kelompok kontrol adalah seluruh data terdistribusi normal. Kemudian untuk hasil pengujian homogenitas pada data penguasaan kosakata pada kelompok eksperimen serta kelompok kontrol disimpulkan bahwa varian antar kelompok sama atau homogen.

Uji hipotesis dilakukan dengan menggunakan uji Anacova berbantuan SPSS 23. Uji hipotesis dilakukan untuk mengetahui pengaruh metode permainan kata teka-teki silang dan Anagram terhadap penguasaan kosakata. Hasil pengujian hipotesis disajikan pada tabel 2. 
Tabel 2. Hasil Uji Hipotesis Penguasaan Kosakata

\begin{tabular}{lcrcrr}
\multicolumn{7}{c}{ Dependent Variable: Posttest_Kosakata } \\
\hline Source & Type III Sum of Squares & Df & Mean Square & F & Sig. \\
\hline Corrected Model & $6760,679^{a}$ & 2 & 3380,339 & 32,206 &, 000 \\
Intercept & 1400,871 & 1 & 1400,871 & 13,347 &, 001 \\
Pretest Kosakata & 2113,984 & 1 & 2113,984 & 20,141 &, 000 \\
Kelas & 3852,776 & 1 & 3852,776 & $36,708,000$ \\
Error & 3463,627 & 33 & 104,958 & & \\
\hline Total & 142599,000 & 36 & & & \\
Corrected Total & 10224,306 & 35 & &
\end{tabular}

Berdasarkan tabel 2 hasil uji hipotesis yang dilakukan dengan bantuan SPSS 23 diperoleh hasil bahwa Sig. 0,000< 0,05 sehingga karena signifikansi lebih kecil dari 0,005 maka dapat ditarik disimpulkan metode permainan kata teka-teki silang dan Anagram berpengaruh signifikan kepada penguasaan kosakata bahasa Indonesia peserta didik kelas IV di SDIT AlIstiqomah Pace.

\section{PEMBAHASAN}

Hasil pengujian Anacova setelah dianalisis menyimpulkan metode permainan teka-teki silang berpengaruh signifikan atas penguasaan kosakata peserta didik kelas IV di SDIT Al-Istiqomah Pace. Pengaruh dapat dilihat dari nilai Sig. $0,000<0,005$. Pengaruh juga dapat dilihat dari nilai rata-rata kelompok eksperimen yang lebih tinggi dari kelompok kontrol. Kelompok eksperimen nilai rata-rata posttest sebesar 72 lebih besar dibanding kelas kontrol yang hanya 49.

Permainan dalam pembelajaran menurut (Taheri, 2014) dapat mempermudah siswa mempelajari kosakata karena dapat mengurangi kecemasan siswa ketika mempelajari kosakata. Selain itu, permainan kosakata juga dapat mendorong siswa yang pasif terlibat langsung dalam pembelajaran. Permainan yang dapat digunakan dalam mengajarkan kosakata adalah teka-teki silang dan Anagram, menurut (Raines, 2010) teka-teki silang dapat memotivasi peserta didik untuk aktif mencari informasi dari kata-kata yang ditampilkan.

Mendukung penelitian terdahulu salah satunya adalah penelitian yang dilakukan (Perveen et al., 2016) pada penelitiannya menyimpulkan bahwa penguasaan kosakata lebih efektif diajarkan kepada peserta didik melalui permainan. (Rohani \& Pourgharib, 2013) dalam penelitian yang dilakukan juga menyimpulkan bahwa penerapan permainan pada pembelajaran kosakata memberikan pengaruh yang positif dan signifikan. Selanjutnya, melalui penelitian yang dilakukan oleh (Derakhshan \& Khatir, 2015) diperoleh hasil bahwa dengan menggunakan permainan kosakata dalam pembelajaran dapat membuat pembelajaran menjadi lebih komunikatif, menarik, dan efektif.

Metode permainan kata teka-teki silang dan Anagram yang diberikan di kelas eksperimen memberikan pengaruh yang positif dibandingkan dengan peserta didik yang tidak menerima permainan teka-teki silang dan Anagram sehingga penguasaan kosakata pada peserta didik sekolah dasar dapat berkembang dan meningkat sesuai dengan indikator kosakata yang harus dikuasai oleh peserta didik kelas IV sekolah dasar.

\section{SIMPULAN}

Permainan kata teka-teki silang berpengaruh terhadap penguasaan kosakata peserta didik. Dibuktikan melalui pengujian Anacova dengan perolehan nilai Sig. 0,000<0,05. Bukti lain dapat dilihat dari nilai rata-rata penguasaan kosakata di kelompok eksperimen yang lebih tinggi dibanding dengan nilai rata-rata penguasaan kosakata di kelompok kontrol. Hal ini dikarenakan pada permainan kata teka-teki silang dan Anagram peserta didik mendapat kesempatan untuk terlibat secara langsung dalam menyusun kata-kata sesuai dengan petunjuk yang diberikan.

Berdasarkan hasil penelitian, beberapa saran yang dapat diberikan peneliti sebagai berikut. Pertama, bagi guru hendaknya memperhatikan pengelolaan waktu selama proses pembelajaran, sesuaikan kosakata yang akan diajarkan dengan materi pembelajaran sehingga peserta didik dapat lebih mudah untuk mempelajari kosakata, kemudian hendaknya guru juga dapat menggunakan hasil penelitian ini dalam pembelajaran untuk meningkatkan mutu peserta didik mengenai penguasaan kosakata. Kedua, bagi peneliti lain hendaknya menyesuaikan kebutuhan kosakata yang akan diajarkan dengan kebutuhan siswa.

\section{DAFTAR RUJUKAN}

Alqahtani, M. (2015). The Importance of Vocabulary in Language Learning and How To Be Taught. International Journal of Teaching and Education, III(3), 21-34. https://doi.org/10.20472/TE.2015.3.3.002

Broadhead, P., Howard, J., \&Woods, E. (2017). Bermain dan Belajar pada Usia Dini dari Penelitian ke Praktik. Terjemahan Julie Medikawati. Jakarta: Indeks Jakarta.

Derakhshan, A., \& Khatir, E. D. (2015). The Effects of Using Games on English Vocabulary Learning. Journal of Applied Linguistics and Language Research, 2(3), 39-47. 
Hurlock, E. B. (2009). Psikologi Perkembangan: Suatu Perkembangan Sepanjang Rentan Kehidupan. Jakarta: Erlangga.

Masri, A. Al., \& Najar, M. Al. (2014). The Effect of Using Word Games on Primary Stage Students Achievement in English Language Vocabulary in Jordan. American International Journal of Contemporary Research, 4(9), 144-152.

Muncer, S., \& Knight, D. (2011). The Syllable Effect In Anagram Solution: Unrecognised Evidence from Past Studies. Journal of Psycholinguistic Research, 40(2), 1-20. https://doi.org/10.1007/s10936-010-9159-6

Perveen, A., Asif, M., Mehmood, S., Kamal Khan, M., \& Iqbal, Z. (2016). Efectiveness of Language Games in Second Language Vocabulary Acquisition. Sci.Int.(Lahore), 28(1), 633-637.

Putra, P. A., Agung, A. A. G., \& Sulastri, N. (2014). Pengaruh Model Pembelajaran Scramble Berbantuan Media Permainan Teka-Teki Silang terhadap Hasil Belajar Bahasa Indonesia Siswa Kelas V SD Negeri 1 Sangsit. Jurnal Mimbar PGSD Universitas Pendidikan Ganesha, 2(1).

Raines, D. A. (2010). An Innovation to Facilitate Student Engagement and Learning: Crossword Puzzles In The Classroom. Teaching and Learning in Nursing, 5(2), 85-90. https://doi.org/10.1016/j.teln.2008.08.003

Rohani, M., \& Pourgharib, B. (2013). The Effect of Games on Learning Vocabulary. International Research Journal of Applied and Basic Sciences, 4(11), 3540-3543.

Rosadi, A. (2017). The Effectiveness of Anagram Technique in Teaching Vocabulary. Voices of English Language Education Society, 1(1), 41-50.

Semmar, Y., \& Al-Thani, T. (2015). Piagetian and Vygotskian Approaches to Cognitive Development in the Kindergarten Classroom. Journal of Educational and Developmental Psychology, 5(2), 1-7. https://doi.org/10.5539/jedp.v5n2p1

Taheri, M. (2014). The Effect of Using Language Games on Vocabulary Retention of Iranian Elementary EFL Learners. Journal of Language Teaching and Research, 5(3), 544-549. https://doi.org/10.4304/jltr.5.3.544-549

Wahyu, D. (2017). Pengaruh Model Teams Games Tournament Berbantuan Permainan Halma terhadap Minat dan Hasil Belajar pada Materi Bunyi Siswa Kelas IV SDN Grujugan Bondowoso. Tesis tidak diterbitkan. Universitas Negeri Malang, Malang.

Zirawaga, V. S., Olusanya, A. I., \& Maduku, T. (2017). Gaming in Education: Using Games as a Support Tool to Teach History. Journal of Education and Practice, 8(15), 55-64.

Zulela. (2013). Pembelajaran Bahasa Indonesia: Apresiasi Sastra di Sekolah Dasar. Bandung: Remaja Rosdakarya. 